\title{
Using remote sensing to evaluate the spatial variability of evapotranspiration and crop coefficient in the lower Rio Grande Valley, New Mexico
}

\author{
Zohrab Samani · A. Salim Bawazir • \\ Max Bleiweiss · Rhonda Skaggs · John Longworth • \\ Vien D. Tran · Aldo Pinon
}

Received: 15 October 2008/Accepted: 2 June 2009/Published online: 26 August 2009

(C) Springer-Verlag 2009

\begin{abstract}
Pecan is a major crop in the lower Rio Grande Valley (LRGV), New Mexico. Currently, about 11,000 ha of pecan orchards at various stages of growth are consuming about $40 \%$ of irrigation water in the area. Pecan evapotranspiration (ET) varies with age, canopy cover, soil type and method of water management. There is a need for better quantification of pecan ET for the purpose of water rights adjudication, watershed management and agronomical practices. This paper describes a process where remote sensing information from Landsat-5 and Landsat-7 were combined with ground level measurements to estimate pecan ET and field scale actual crop coefficient $\left(K_{\mathrm{c}}\right)$ for the LRGV. The results showed that annual pecan water use for 279 fields ranged from 498 to $1,259 \mathrm{~mm}$ with an average water use of $1,054 \mathrm{~mm}$. For fields with NDVI $>0.6$ (normalized difference vegetation index), which represented mature orchards (total of 232 fields), the annual water use ranged from 771 to $1,259 \mathrm{~mm}$ with an average water use of $1,077 \mathrm{~mm}$. The results from remote sensing model compared reasonably well with ground level ET values determined by an eddy covariance system in a mature pecan orchard with an average error of $4 \%$ and the standard error of estimate (SEE) ranging from 0.91 to $1.06 \mathrm{~mm} /$ day. A small fraction $(5 \%)$ of the pecan fields were within the range of maximum ET and $K_{\mathrm{c}}$.
\end{abstract}

Communicated by S. Ortega-Farias.

Z. Samani $(\varangle)$ · A. S. Bawazir · M. Bleiweiss · R. Skaggs ·

V. D. Tran · A. Pinon

New Mexico State University, Las Cruces, USA

e-mail: zsamani@nmsu.edu

J. Longworth

New Mexico Office of the State Engineer, Las Cruces, USA

\section{Introduction}

The lower Rio Grande Valley (LRGV) is a major agricultural area in southern New Mexico. The mean annual precipitation is about $200 \mathrm{~mm}$. The irrigated agriculture in the area depends on surface water from Rio Grande and supplemental groundwater. Water is a limiting factor in crop production in the valley. The annual surface water allotment ranges from $12,000 \mathrm{~m}^{3}$ to as low as $1,500 \mathrm{~m}^{3} / \mathrm{ha}$ annually. Pecan, alfalfa and cotton are the main crops grown in the area. The LRGV is one of the major pecan producers in the nation. Currently, there are about 1,056 producers growing pecans on about 11,000 ha of land. The LRGV produces an average of 22,000 tons of pecan annually with an estimated value of about $\$ 100$ million.

Pecan water use varies depending on plant density, age, canopy cover and moisture availability. Water management is a critical factor in the productivity of pecan, and crop yield varies significantly with the availability of water. Limited information is available on the spatial and temporal variabilities of water use by pecan. The question of water requirements is complicated by the variation in pecan age, soil type, irrigation management and pruning practices.

Pecan is known to consume large amounts of water. Miyamoto (1983) evaluated water use (or ET) of commercially surface-irrigated pecan trees in seven commercial orchards in the LRGV (El Paso, TX-Las Cruces, NM valleys). The test sites were located $20 \mathrm{~km}$ apart at Texas A\&M Research Farm, El Paso, TX and at the New Mexico State University Experimental Farm, Las Cruces, NM. The trees studied ranged in age from 8 to 35 years, had trunk diameters that ranged in size from 13 to $53 \mathrm{~cm}$. The 8-yearold trees had a trunk diameter of $13 \mathrm{~cm}$ and were about $7 \mathrm{~m}$ tall while the 35-year-old ones had a trunk diameter of 
about $53 \mathrm{~cm}$ and were about $19 \mathrm{~m}$ tall. The orchard's spacing ranged from $9.1 \mathrm{~m} \times 9.1 \mathrm{~m}$ to $10.6 \mathrm{~m} \times 12.2 \mathrm{~m}$. Three out of seven orchards were spaced in a rectangular arrays and the rest in staggered or offsetting arrays. Out of the seven orchards, five were studied by the US Bureau of Reclamation in 1972 and 1973 while two orchards (8 years old) were studied in 1981 by Miyamoto (1983). Consumptive water use was determined by Miyamoto (1983) from measured soil water depletion using neutron moisture probe at depths of $18,30,45,60,90$ and $120 \mathrm{~cm}$ in 14 access tubes placed around the test trees in radial directions toward north and south; root depths of pecan trees at the study site was determined in general not to exceed $120 \mathrm{~cm}$. Miyamoto (1983) reported pecan water use for the growing season ranging from 368 to $1,307 \mathrm{~mm}$ depending on tree size and planting density; high rates between 1,000 and $1,300 \mathrm{~mm}$ were for full-grown trees. Sammis et al. (2004) measured evapotranspiration (ET) of 30-year-old floodirrigated pecans in a 5.1 ha orchard also located on the Rio Grande floodplain in the Mesilla Valley, $7 \mathrm{~km}$ south of Las Cruces, NM. The tree spacing of the orchard was $9.7 \mathrm{~m} \times 9.7 \mathrm{~m}$, with average tree height of $12.8 \mathrm{~m}$, and average tree diameter of $30 \mathrm{~cm}$. Sammis et al. (2004) measured seasonal and annual ET of 1,260 and 1,460 mm in 2001, and 1,170 and $1,370 \mathrm{~mm}$ in 2002, respectively, using one-propeller eddy covariance (OPEC) system. Bawazir and King (2004) measured ET of a flood-irrigated mature (40-65 years old) pecan orchard in 2002 and 2003. The pecan orchard studied by Bawazir and King (2004) was commercially grown on an area of 1,620 ha and was located about $13 \mathrm{~km}$ south of Las Cruces. They used energy budget method utilizing OPEC and three-dimensional eddy covariance system to measure ET. From their measurements, they reported seasonal and annual ET of 1,305 and $1,417 \mathrm{~mm}$ during 2002, and 1,334 and $1,479 \mathrm{~mm}$ in 2003 , respectively. The orchard studied by Bawazir and King (2004) was located about $6 \mathrm{~km}$ south of the orchard studied by Sammis et al. (2004).

Traditionally, ET has been calculated using a crop coefficient $\left(K_{\mathrm{c}}\right)$ multiplied by reference evapotranspiration $\left(\mathrm{ET}_{\mathrm{o}}\right)$ calculated for either grass or alfalfa as:

$\mathrm{ET}=K_{\mathrm{c}} \times \mathrm{ET}_{\mathrm{o}}$.

The $\mathrm{ET}_{\mathrm{o}}$ is often calculated from various equations such as by Hargreaves and Samani (1982, 1985), PenmanMonteith (Allen 1986), ASCE-EWRI (2005) and others. Recently, a dual crop coefficient has been recommended to account for specific wetting events of the crop coefficient, $K_{\mathrm{c}}$ (Allen et al. 1998). This approach consists of splitting $K_{\mathrm{c}}$ into two separate coefficients, one for transpiration which is known as basal crop coefficient $\left(K_{\mathrm{cb}}\right)$ and the other for soil evaporation $\left(K_{\mathrm{e}}\right)$. Either one of these approaches assumes that no limitations are placed on growth or crop evapotranspiration. However, under deficit irrigation practices which are common in dry climates such as in New Mexico, the actual ET is often lower than the estimated ET based on traditional approaches (Samani et al. 2005; Skaggs and Samani 2005). Previous studies in the LRGV (Miyamoto 1983; Wang et al. 2007) on limited number of pecan orchards have shown high variability in crop coefficient and ET. This study was undertaken to assess the spatial and temporal variabilities of $K_{\mathrm{c}}$ and ET for pecan orchards using remote sensing technology on a field scale in the LRGV, New Mexico, USA. Understanding the magnitude and diversity of ET at the field scale is critical for optimizing water management, implementing adjudication and assessing economic returns from water use in the region.

\section{Methodology}

\section{Remote sensing model}

Regional ET Estimation Model (REEM) (Samani et al. 2006; Samani et al. 2007a, b) was used to calculate the daily ET for pecan orchards in LRGV. The model is based on surface energy balance similar to that presented by Bastiaanssen (1995) and Allen et al. (2007) where the latent heat flux (LE) was determined as a residual of the surface energy equation:

$\mathrm{LE}=R_{\mathrm{n}}-G-H$

where LE is the latent heat flux, $R_{\mathrm{n}}$ the net radiation flux at the surface, $G$ the soil heat flux and $H$ is the sensible heat flux. All units are in $\mathrm{MJ} /\left(\mathrm{m}^{2} \mathrm{day}\right)$.

Daily net radiation over crop canopy was calculated using a methodology developed by Samani et al. (2007a, b) as:

$R_{\mathrm{n}}=R_{\mathrm{ni}}\left(\frac{R_{\mathrm{s}}}{R_{\mathrm{si}}}\right)\left(\frac{T_{\mathrm{a}}}{T_{\mathrm{i}}}\right)^{4}$

where $R_{\mathrm{n}}$ is the daily net radiation in $\mathrm{MJ} /\left(\mathrm{m}^{2}\right.$ day $), R_{\mathrm{ni}}$ the instantaneous clear sky net radiation $\left(\mathrm{W} / \mathrm{m}^{2}\right), R_{\mathrm{s}}$ the daily short wave solar radiation $\left[\mathrm{MJ} /\left(\mathrm{m}^{2}\right.\right.$ day $\left.)\right], R_{\mathrm{si}}$ the instantaneous short wave solar radiation $\left(\mathrm{W} / \mathrm{m}^{2}\right), T_{\mathrm{a}}$ is average daily temperature $(\mathrm{K})$ and $T_{\mathrm{i}}$ is the instantaneous air temperature $(\mathrm{K})$.

The instantaneous net radiation $\left(R_{\mathrm{ni}}\right)$ was calculated based on a procedure as utilized by Bastiaanssen (1995) for estimating instantaneous net radiation $\left(R_{\mathrm{ni}}\right)$ :

$R_{\mathrm{ni}}=(1-\alpha) R_{\mathrm{si}} \downarrow+\mathrm{RL} \downarrow-\mathrm{RL} \uparrow-\left(1-\varepsilon_{\mathrm{o}}\right) \mathrm{RL} \downarrow$

where $R_{\mathrm{ni}}$ is the instantaneous net radiation $\left(\mathrm{W} / \mathrm{m}^{2}\right), R_{\mathrm{si}} \downarrow$ the instantaneous incoming short wave radiation $\left(\mathrm{W} / \mathrm{m}^{2}\right)$, $\mathrm{RL} \downarrow$ the instantaneous incoming longwave radiation 
$\left(\mathrm{W} / \mathrm{m}^{2}\right), \mathrm{RL} \uparrow$ the instantaneous outgoing longwave radiation $\left(\mathrm{W} / \mathrm{m}^{2}\right), \alpha$ the surface albedo (dimensionless) and $\varepsilon_{\mathrm{O}}$ is the surface emissivity (dimensionless).

$\mathrm{RL} \downarrow$ and $\mathrm{RL} \uparrow$ are calculated as follows:

$\mathrm{RL} \downarrow=\varepsilon_{\mathrm{a}} \times \sigma \times T_{\mathrm{i}}^{4}$

where $\varepsilon_{\mathrm{a}}$ is atmospheric emissivity calculated using the following equation (Bastiaanssen 1995):

$\varepsilon_{\mathrm{a}}=0.85\left(-\ln \tau_{\mathrm{sw}}\right)^{0.09}$.

The $\sigma$ is the Stefan-Boltzman constant $\left[5.67 \times 10^{-8}\right.$ $\left.\mathrm{W} /\left(\mathrm{m}^{2} \mathrm{~K}^{4}\right)\right], \quad T_{\mathrm{i}}$ the instantaneous near surface air temperature $(\mathrm{K}), \tau_{\mathrm{sw}}$ is the atmospheric transmissivity calculated from elevation (Allen et al. 1998) and

$\mathrm{RL} \uparrow=\varepsilon_{\mathrm{o}} \times \sigma \times T_{\mathrm{s}}^{4}$

where $\varepsilon_{\mathrm{O}}$ is surface thermal emissivity (dimensionless) calculated using an empirical equation " $\varepsilon_{\mathrm{o}}=0.95+0.01$ LAI" developed by Tasumi (2003) for bare soil (LAI =0) to the fully covered agricultural field condition ( $\mathrm{LAI}=3$ ) at Kimberly, Idaho. When the LAI > 3, LAI was set equal to 3. LAI is the leaf area index, and $T_{\mathrm{s}}$ is the surface temperature $(\mathrm{K})$. The LAI is the ratio of total upper leaf surface area of vegetation divided by the surface area of the land on which the vegetation grows $\left(\mathrm{m}^{2} / \mathrm{m}^{2}\right)$.

The satellite data from Landsat-5 (year 2002) and Landsat-7 (year 2003) were used to calculate Normalized Difference Vegetation Index (NDVI, Eq. 8), albedo, and surface temperature for the study site. The Landsat sensor makes multispectral observations in seven wavelength regions as shown in Table 1 . Remote sensing software package ENVI ${ }^{\circledR}$, by Research Systems Inc., Boulder, CO, and its many tools were used for data processing.

The NDVI was calculated using the following equation:

$\mathrm{NDVI}=\frac{\rho_{\text {nir }}-\rho_{\text {red }}}{\rho_{\text {nir }}+\rho_{\text {red }}}$

where $\rho$ is surface reflectance for Landsat-5 Thematic Mapper (TM) and Landsat-7 Enhanced Thematic Mapper

Table 1 Landsat multispectral bands

\begin{tabular}{lcll}
\hline Band no. & $\begin{array}{l}\text { Wavelength } \\
\text { interval }(\mu \mathrm{m})\end{array}$ & $\begin{array}{l}\text { Spectral } \\
\text { response }\end{array}$ & $\begin{array}{l}\text { Resolution } \\
(\mathrm{m})\end{array}$ \\
\hline 1 & $0.45-0.52$ & Blue-Green & 30 \\
2 & $0.52-0.60$ & Green & 30 \\
3 & $0.63-0.69$ & Red & 30 \\
4 & $0.76-0.90$ & Near IR & 30 \\
5 & $1.55-1.75$ & Mid-IR & 30 \\
6 & $10.40-12.50$ & Thermal IR & $60,120^{\mathrm{a}}$ \\
7 & $2.08-2.35$ & Mid-IR & 30 \\
\hline
\end{tabular}

${ }^{a}$ Landsat- 5 is $120 \mathrm{~m}$, while Landsat- 7 is $60 \mathrm{~m}$
Plus (ETM+), the near-infrared (nir) band is band 4 and the red band is band 3 .

Albedo $(\alpha)$ was calculated using the methodology described by Liang et al. (2002):

$$
\begin{aligned}
\alpha= & 0.356 \rho_{1}+0.13 \rho_{3}+0.373 \rho_{4}+0.085 \rho_{5}+0.072 \rho_{7} \\
& -0.0018
\end{aligned}
$$

where $\rho_{\mathrm{i}}$ is the reflectance in band $\mathrm{i}$.

The thermal radiation observed by satellite is converted to $T_{\mathrm{s}}$ using a methodology proposed by Barsi et al. (2005):

$L_{\mathrm{TOA}}=\tau \varepsilon_{\mathrm{o}} L_{\mathrm{T}}+L_{\mathrm{u}}+\tau\left(1-\varepsilon_{\mathrm{o}}\right) L_{\mathrm{d}}$

where $L_{\mathrm{TOA}}$ is the space-reaching or top of atmosphere (TOA) radiance measured by the satellite instrument, $\tau$ the atmospheric transmissivity, $L_{\mathrm{T}}$ the target radiance with a blackbody surface emissivity of $1, L_{\mathrm{u}}$ the upwelling or atmospheric path radiance and $L_{\mathrm{d}}$ is the downwelling or sky radiance. Radiances are in units of $\mathrm{W} /\left(\mathrm{m}^{2} \mathrm{sr} \mu \mathrm{m}\right)$ and the transmissivity and emissivity are unitless. The webbased calculator (http://atmcorr.gsfc.nasa.gov/) was used to determine the atmospheric correction parameters necessary to complete the process. The calculator provides the necessary parameters for Eq. 10 with the exception of surface emissivity, $\varepsilon_{\mathrm{o}}$. The $L_{\mathrm{T}}$ was determined by rearranging Eq. 10 as follows:

$L_{\mathrm{T}}=\left[L_{\mathrm{TOA}}-L_{\mathrm{u}}-\tau\left(1-\varepsilon_{\mathrm{o}}\right) L_{\mathrm{d}}\right] / \tau \varepsilon_{\mathrm{O}}$.

The $L_{\mathrm{T}}$ is then converted to radiometric temperature at the surface $\left(T_{\mathrm{s}}\right)$ using the Planck equation:

$T_{\mathrm{s}}=K_{2} / \ln \left(1+K_{1} / L_{\mathrm{T}}\right)$

where $K_{1}$ equals to 666.09 and 607.76 for Landsat-7 and Landsat-5, respectively, and $K_{2}$ equals to $1,282.71$ and 1,260.56 for Landsat-7 and Landsat-5, respectively (Barsi et al. 2005).

Using ground heat flux data ranging from 35 to $150 \mathrm{~W} / \mathrm{m}^{2}$ and NDVI ranging from 0.2 to 0.85 , Samani et al. (2005) developed the following equation to estimate instantaneous soil heat flux $\left(G_{\mathrm{i}}\right)$ at the time of satellite overpass:

$\frac{G_{\mathrm{i}}}{R_{\mathrm{ni}}}=0.26 \mathrm{e}^{(-1.97 \mathrm{NDVI})}$.

The instantaneous sensible heat flux $\left(H_{\mathrm{i}}\right)$ was calculated by combining the aerodynamic equation with MoninObukhov similarity theory. The aerodynamic equation (Bastiaanssen 1995) is defined as:

$H_{\mathrm{i}}=\rho_{\mathrm{a}} C_{\mathrm{p}} \frac{T_{\mathrm{o}}-T_{\mathrm{a}}}{r_{\mathrm{ah}}}=\rho_{\mathrm{a}} C_{\mathrm{p}} \frac{\mathrm{d} T}{r_{\mathrm{ah}}}$

where $\rho_{\mathrm{a}}$ is the air density $\left(\mathrm{kg} / \mathrm{m}^{3}\right), C_{\mathrm{p}}$ the specific heat of air $[1,004 \mathrm{~J} /(\mathrm{kg} \mathrm{K})], \quad T_{\mathrm{o}}$ the aerodynamic surface temperature $(\mathrm{K}), T_{\mathrm{a}}$ the air temperature $(\mathrm{K}), r_{\mathrm{ah}}$ the 
aerodynamic surface resistance and $\mathrm{d} T$ is the air temperature gradient calculated using a linear function described by Bastiaanssen (1995):

$\mathrm{d} T=a T_{\mathrm{s}}+b$

where $a$ and $b$ are calibration constants that are empirically determined using reference extreme points on the ground. Calibration of Eq. 15 requires a minimum of two points on the ground where $\mathrm{d} T$ values can be calculated from sensible heat $\left(H_{\mathrm{i}}\right)$ fluxes using Eq. 14. In this study, two sensible heat values were used. One sensible heat value was measured using OPEC eddy covariance system in a mature, well-watered pecan orchard which extended more than $5 \mathrm{~km}$ in the predominant wind direction as shown in Fig. 1.

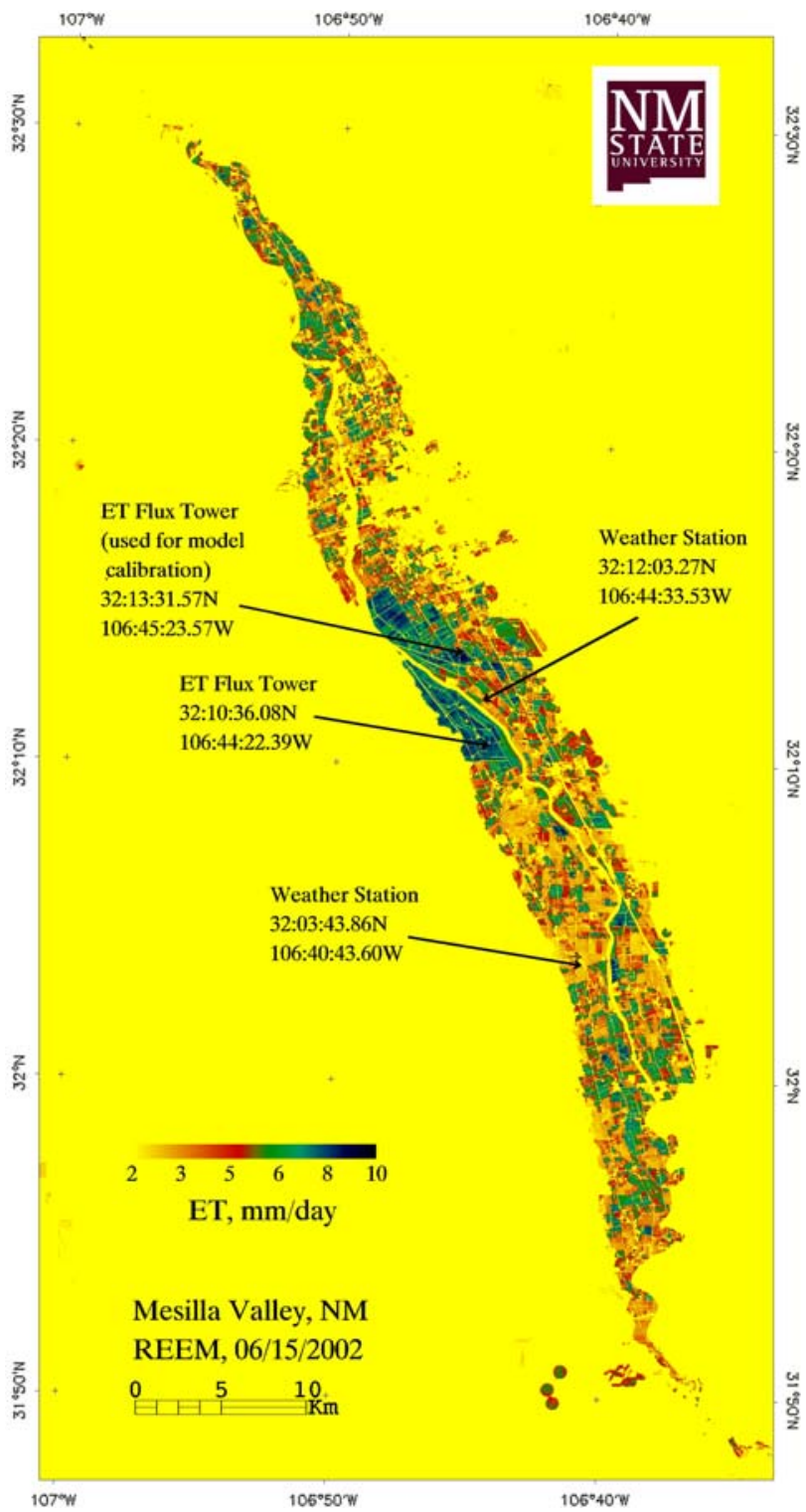

Fig. 1 ET distribution in the lower Rio Grande Valley (LRGV) for 16 June 2002 and location of eddy covariance flux towers and weather stations
The other sensible heat value was estimated for a dry fallow field with no vegetation by setting instantaneous latent heat $\left(\mathrm{LE}_{\mathrm{i}}\right)$ equal to zero and estimating instantaneous $R_{\text {ni }}$ and ground flux $G_{\mathrm{i}}$ from Eqs. 4 and 13. The $H_{\mathrm{i}}$ value for the dry field was then calculated as a residual of the energy balance as:

$H_{\mathrm{i}}=R_{\mathrm{ni}}-G_{\mathrm{i}}$.

The aerodynamic resistance $\left(r_{\mathrm{ah}}\right)$ in Eq. 14 was calculated using wind speed extrapolated from blending height of $200 \mathrm{~m}$ and an iterative stability correction based on Monin-Obukhov similarity theory (Bastiaanssen 1995; Allen et al. 2007).

Once the values of " $a$ " and " $b$ " in Eq. 15 were estimated, then the sensible heat flux at the time of satellite overpass was calculated for each pixel using Eqs. 14 and 15. During the calculation of sensible heat flux, $r_{\mathrm{ah}}$ value for each pixel was calculated iteratively as described earlier. The other components of the energy, $R_{\mathrm{ni}}$ and $G_{\mathrm{i}}$, for the time of satellite overpass were calculated using Eqs. 4 and 13 .

The evaporative fraction $\left(E_{\mathrm{f}}\right)$ for each pixel is defined as the ratio of the latent heat flux to the available energy and is calculated using the values of $H_{\mathrm{i}}, G_{\mathrm{i}}$ and $R_{\mathrm{ni}}$ :

$E_{\mathrm{f}}=\frac{R_{\mathrm{ni}}-G_{\mathrm{i}}-H_{\mathrm{i}}}{R_{\mathrm{ni}}-G_{\mathrm{i}}}$.

Once the evaporative fraction is calculated and assuming that evaporative fraction is constant over the 24-h period, the daily ET can be calculated by multiplying $E_{\mathrm{f}}$ by daily available energy as:

$\mathrm{ET}=E_{\mathrm{f}}\left(R_{\mathrm{n}}-G\right)$.

Assuming daily $G$ as negligible (Allen et al. 1998), daily ET can be calculated by multiplying $E_{\mathrm{f}}$ by the daily net radiation $\left(R_{\mathrm{n}}\right)$.

Field measurements

Evapotranspiration of a mature pecan orchard was determined using eddy covariance method. It was calculated as a residual in the energy balance by measuring net radiation, soil heat and sensible heat fluxes, as recommended by Blanford and Gay (1992). Net radiation was measured using Q7.1 net radiometer (Radiation and Energy Balance Systems, Inc., Seattle, Washington). The soil heat flux was measured using four soil heat flux plates (Radiation and Energy Balance Systems, Inc., Seattle, Washington) buried at the surface with two under the canopy and two between the rows. The sensible heat flux was measured using a pair of OPEC system (Blanford and Gay 1992; Amiro and Wuschke 1987). A pair of OPEC system was used to ensure consistency in data collection. The OPEC system consisted of a gill propeller anemometer model 27106 
(R.M. Young Company, Traverse City, Michigan) and a 76- $\mu \mathrm{m}$ diameter type $\mathrm{E}$ fine-wire thermocouple (Campbell Scientific Inc., Logan, Utah). Three components of net radiation, sensible heat and soil heat fluxes were measured at a frequency of 15,000 samples every $30 \mathrm{~min}$.

The orchard was located about $13 \mathrm{~km}$ south of Las Cruces, NM in the Mesilla Valley and adjacent to the Rio Grande [World Geodetic System (WGS) 84: latitude $32^{\circ} 10^{\prime} 36.08^{\prime \prime} \mathrm{N}$, longitude $106^{\circ} 44^{\prime} 22.39^{\prime \prime} \mathrm{W}$ and altitude $1,144 \mathrm{~m}$ above mean sea level] as shown in Fig. 1. The orchard was composed of mature pecan trees ranging in age from 40 to 65 years and of the variety 'Western Schley'. It was flood irrigated with water from the Rio Grande via irrigation canals and supplemental water from groundwater. The orchard terrain was composed of laserleveled flat land. The Rio Grande was located on the east border and a naturally occurring mesa was located on the west. The Santo Tomas Mountains were located to the west with elevations of about 1,213 m. Agricultural lands were located in every direction of the orchard and to the east side of the Rio Grande.

The orchard where the measurements were conducted stretched about $2.4 \mathrm{~km}$ wide and $4.8 \mathrm{~km}$ long. A 23-m triangulated tower was used to mount the sensors for measuring the components of the energy budget. The trees were about $16 \mathrm{~m}$ tall on average with trunk diameters ranging from 38 to $50 \mathrm{~cm}$ and were spaced about 9 by $9 \mathrm{~m}$. The eddy covariance instruments were mounted at about $7 \mathrm{~m}$ above the canopy allowing a minimal fetch-to-instrument-height ratio of 340 .

Sensible heat fluxes measured with OPEC system were compared with measurements using a three-dimensional sonic eddy covariance system (Campbell Scientific Inc., Logan, Utah) for a period of 41 days in 2003 when sonic measurements were available. The sensible heat fluxes measured by sonic eddy covariance system (3D-sonic anemometer, Model CSAT3) were corrected for humidity effect according to Schotanus et al. (1983) as applied by Massman and Lee (2002). In addition, the sensible heat fluxes were corrected for frequency response including line averaging and block averaging according to Massman (2000, 2001). The comparison of sensible heat (24 h total) values for the 41 days resulted in a ratio of 0.98 (Sonic-H/ OPEC-H) and a standard error of estimate (SEE, Eq. 19) of $0.65 \mathrm{MJ}\left(\mathrm{m}^{2}\right.$ day $)$. For the same period, the latent heat fluxes were measured with 3D-sonic anemometer and krypton hygrometer (Campbell Scientific Inc. Logan, Utah). The data were corrected for oxygen (Tanner et al. 1993; Van Dijk et al. 2003), and for frequency response including line averaging, block averaging, and sensor separation (Massman 2000, 2001). Latent heat fluxes were also corrected for water vapor density effect (Webb et al. 1980; Massman and Lee 2002). The average of the energy budget closure for the period of comparison ( $n=41$ days) was 0.78 with standard deviation of 0.12 .

The latent heat fluxes for the entire growing season were not directly measured, instead they were calculated as a residual in the energy budget, assuming the energy budget closed as recommended by Blanford and Gay (1992). Evapotranspiration, in equivalent depth of water, was then determined by dividing the latent heat flux by latent heat of vaporization of water $(\sim 2.45 \mathrm{MJ} / \mathrm{kg})$.

\section{Comparison of predicted and measured ET}

The daily water use was calculated using the remote sensing for the clear days where satellite data were available. A total of 12 scenes were available for the year 2002 and 10 scenes for the year 2003. Using the calculated daily ET values, crop coefficients were calculated by dividing daily ET values by standardized grass-referenced evapotranspiration $\left(\mathrm{ET}_{\mathrm{sz}}\right)$ (ASCE-EWRI 2005). The daily $\mathrm{ET}_{\mathrm{sz}}$ was calculated using weather data from automated weather station located in near-by agricultural area. For the days where useable satellite images were not available, $K_{\mathrm{c}}$ was interpolated using Piecewise Cubic Hermite Interpolation Polynomial (PCHIP) technique (Fritch and Carlson 1980; Kahaner et al. 1988). The interpolated $K_{\mathrm{c}}$ values were then used to estimate daily ET by multiplying the daily $K_{\mathrm{c}}$ values by daily $\mathrm{ET}_{\mathrm{sz}}$. Figures 2 and 3 compare the predicted and measured ET values for a mature pecan orchard around the location of the ET flux tower. The ratio of predicted versus measured annual ET were 1.01 and 0.96 for year 2002 and 2003, respectively (Table 2). The SEE for daily ET was 1.06 and $0.91 \mathrm{~mm} /$ day for the year 2002 and 2003, respectively. The SEE was calculated as:

$\mathrm{SEE}=\sqrt{\frac{\sum\left(y-y^{\prime}\right)^{2}}{n-1}}$

where $y$ is the measured ET values and $y^{\prime}$ is the REEM predicted daily ET values for $n=365$ days.

\section{Results and discussion}

The latent heat flux in this study was not directly measured but was calculated as a residual in the energy budget [closure, $(\mathrm{LE}+H) /\left(R_{\mathrm{n}}-G\right)=1$ ]. The sensible heat flux was measured by the OPEC system. The sensible heat flux was a small component of the net radiation (less than 10\%) during the growing season. Therefore, any potential error in the eddy covariance measurement of sensible heat flux would only have a small effect on the calculation of ET as a residual in the energy budget. Predicted and measured ET 




Fig. 2 Comparison of daily measured and predicted pecan ET for year 2002



Fig. 3 Comparison of daily measured and predicted pecan ET for year 2003

Table 2 Comparison of measured and predicted annual and daily ET for the year 2002 and 2003

\begin{tabular}{llllll}
\hline Year & \multicolumn{2}{l}{ Annual ET $(\mathrm{mm})$} & & Daily ET (mm/day) & \\
\cline { 2 - 3 } \cline { 6 - 6 } & Predicted & Measured & & Ratio (predicted/measured) & SEE \\
\hline 2002 & $1,374.5$ & $1,357.3$ & & 1.01 & 1.06 \\
2003 & $1,414.8$ & $1,470.7$ & & 0.96 & 0.91 \\
\hline
\end{tabular}

(Figs. 2, 3) compared reasonably well (SEE $=0.96 \mathrm{~mm} /$ day for 2002 and $1.06 \mathrm{~mm} /$ day for 2003) and the annual ET difference was less than 4\%. Even though the average differences between predicted and measured seasonal and annual ET were low, the differences between predicted and measured daily ET were high for those periods where time intervals between the satellite images were large. The differences were more pronounced especially for the periods where there were rapid changes in crop coefficients such as during early and late parts of the growing season.
Figure 4 shows the annual ET as a function of the field size for 279 pecan orchards for 2002. There was larger variability in annual ET for smaller fields. This is probably due to higher diversity of management in smaller fields compared to large commercial and well managed fields. Figure 5 shows the histogram of the annual pecan ET for the same fields. The annual ET for the 279 fields ranged from 498 to $1,259 \mathrm{~mm}$ with an average of $1,054 \mathrm{~mm}$.

Figure 6 shows the histogram of annual ET for 232 orchards during the year 2002 with NDVI values greater than 0.6. The NDVI value of 0.6 represents mature pecan orchards with canopy cover greater than $60 \%$. This histogram is closer to a normal distribution when compared to Fig. 4, which is more skewed. The annual ET values in Fig. 6 ranged from 771 to $1,259 \mathrm{~mm}$ with an average value of $1,077 \mathrm{~mm}$. This shows that even in mature pecan fields there is large variability in annual ET. Only about $5 \%$ of pecan fields had an annual ET within the range of 1,200$1,300 \mathrm{~mm}$ which is the average ET for a well managed and mature pecan orchard (NDVI $>0.6$ ). Figure 7 shows the histogram of annual $K_{\mathrm{c}}$ for the 279 orchards. The histogram shows a maximum annual and average $K_{\mathrm{c}}$ value of 0.7 and 0.55 , respectively. This results show that the pecan orchards do not have a single crop coefficient and there is a significant variation in $K_{\mathrm{c}}$ values among the orchards.

The remote sensing modeling of ET for various pecan fields in the LRGV showed large variability. In this case, the theoretical approach commonly used in calculating annual ET such crop coefficient approach (Eq. 1) for pecan orchards will not be practical. The study shows that there is a potential in improving water management in fields with lower ET which can potentially result in increased yield. Even though other factors as such nutrient deficiency, disease, soil physical and chemical properties can result in reduction of ET, previous research (Samani et al. 2005; Skaggs and Samani 2005) have shown that there is

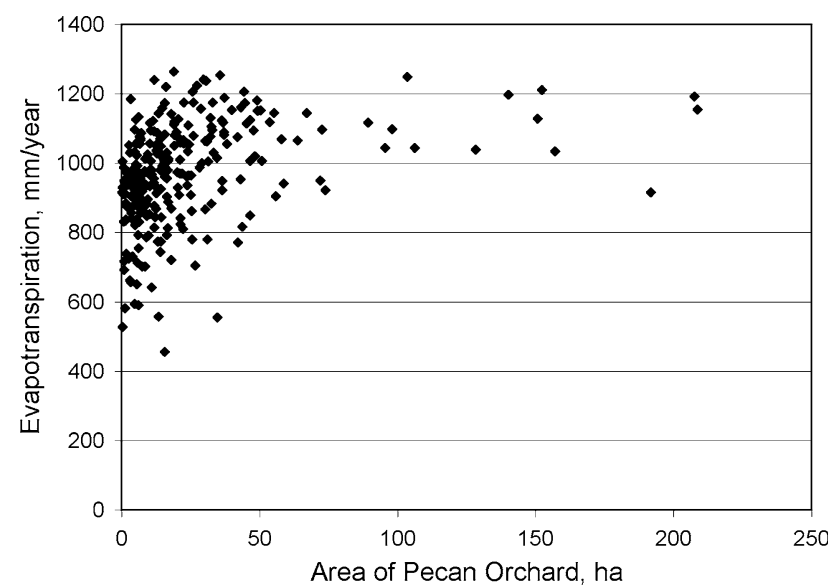

Fig. 4 Annual average ET of various pecan fields versus the area of the orchard (fields) in the lower Rio Grande Valley (LRGV) 


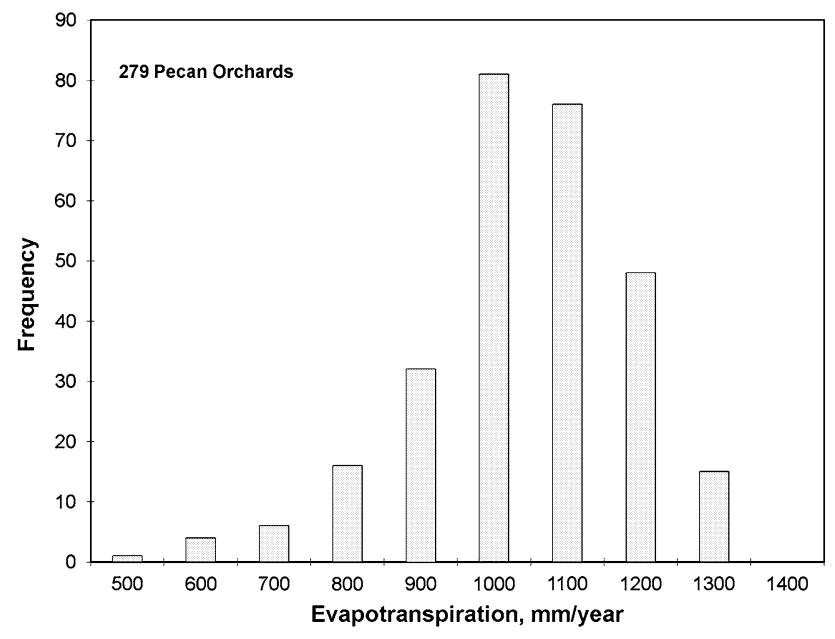

Fig. 5 Histogram of annual ET of 279 pecan fields in the lower Rio Grande Valley (LRGV) for year 2002

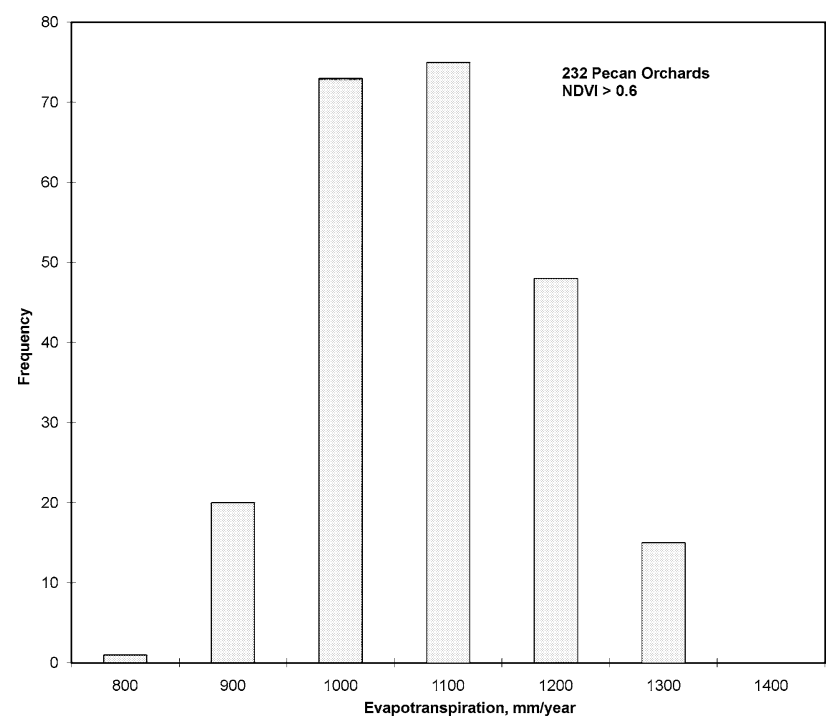

Fig. 6 Histogram of annual ET of 232 mature pecan fields (NDVI > 0.6) in the lower Rio Grande Valley (LRGV) for year 2002

significant variability in water application. Water availability is limited in most fields.

The calculated ET values for pecan in this study using remote sensing was compared with pecan ET data reported by other investigators in Table 3. The comparison shows that the ET estimated from remote sensing was within the range of ET reported by other investigators.

\section{Conclusion}

The findings in this paper reveal that LRGV consumptive use for pecan orchards varies widely. The average crop consumptive use is also less than what would be calculated by reference ET methods utilizing a crop coefficient



Fig. 7 Histogram of annual $K_{\mathrm{c}}$ distribution of pecan fields in the lower Rio Grande Valley (LRGV) for year 2002

Table 3 Comparison of growing season pecan ET reported by various investigators

\begin{tabular}{ll}
\hline Reference & Growing season ET (April-October) $(\mathrm{mm})$ \\
\hline This paper & $413-1,095$ (year 2002) \\
Miyamoto (2003) & $368-1,307$ (year 1972, 1973 and 1981) \\
Sammis et al. (2004) & $1,220-1,267$ (year 2001, 2002) \\
Bawazir and King (2004) & $1,236-1,293$ (year 2002, 2003) \\
\hline
\end{tabular}

derived from optimal conditions. This unique farm-by-farm view of consumptive use provides information that can assist in the development of water administration policies, including proceedings within water right adjudications and assessing agricultural water conservation issues as well as downstream water obligation and surface-groundwater interaction modeling.

Because of the frequent drought in the LRGV, it is often speculated that the implementation of the modern irrigation systems such as drip and sprinkler irrigation would result in water saving. The results of this study show that the majority of the pecan orchards are under water deficit condition. Therefore, implementing modern high efficiency irrigation technologies such as drip and sprinkler systems would most likely result in additional consumptive use by pecan crops. This counter intuitive result has the opposite impact to the LRGV water supply than commonly perceived and would further stress the limited water resources in the area, even though it may increase the income from the individual orchards.

\section{References}

Allen RG (1986) A Penman for all seasons. ASCE J Irrig Drain Eng 112(4):348-368

Allen RG, Pereira LS, Raes D, Smith M (1998) Crop evapotranspiration: guidelines for computing crop water requirements. Food 
and Agriculture Organization, Rome (FAO Irrigation and Drainage Paper no. 56)

Allen RG, Tasumi M, Trezza R (2007) Satellite-based energy balance for mapping for evapotranspiration with internalized calibration. ASCE J Irrig Drain Eng 133(4):380-394

Amiro BD, Wuschke EE (1987) Evapotranspiration from a boreal forest drainage basin using energy balance/eddy correlation technique. Boundary Layer Meteorol 38:125-139

ASCE-EWRI (2005) The ASCE standardized reference evapotranspiration equation. In: Allen RG, Walter IA, Elliot RL, Howell TA, Itenfisu D, Jensen ME, Snyder RL (eds) Reported by the American Society of Civil Engineers (ASCE) Task Committee on Standardization of Reference Evapotranspiration. ASCE, Reston, 0-7844-0805-X, $204 \mathrm{p}$

Barsi JA, Schott JR, Palluconi FD, Hook SJ (2005) Validation of a web-based atmospheric correction tool for single thermal band instruments. In James J. Butler (ed) Earth observing systems X; proceedings of SPIE Conference, 5882. Society of Photo-optical Instrumentation Engineers (SPIE), San Diego, 31 July-2 Aug 2005. Bellingham, pp 136-142

Bastiaanssen WGM (1995) Regionalization of surface flux densities and moisture indicators in composite terrain: a remote sensing approach under clear skies in Mediterranean climates. Ph.D. dissertation, Landbouwuniversiteit te Wageningen, the Netherlands. Published as Report 109 of DLO Win and Staring Centre, Wageningen, The Netherlands

Bawazir AS, King JP (2004) Crop Evapotranspiration (ET) Study for Dona Ana County. New Mexico Water Resources Research Institute, Technical Completion Report, Las Cruces

Blanford JH, Gay LW (1992) Tests of a robust eddy correlation system for sensible heat flux. Theor Appl Climatol 46(1):53-60

Fritch FN, Carlson RE (1980) Monotone piecewise cubic interpolation. SIAM J Numer Anal 17(2):238-246

Hargreaves GH, Samani ZA (1982) Estimating potential evapotranspiration. J Irrig Drain Eng Div ASCE 108(3):225-230

Hargreaves GH, Samani ZA (1985) Reference crop evapotranspiration from temperature. Appl Eng Agric 1(2):96-99

Kahaner D, Cleve M, Stephan N (1988) Numerical methods and software. Prentice Hall, Englewood Cliffs

Liang S, Shuey CJ, Russ AL, Fang H, Chen M, Walthalk CL, Daughtry CST, Hunt R (2002) Narrowband to broadband conversions of land surface albedo: I. Algorithms. Remote Sensing Environ 76:213-238

Massman WJ (2000) A simple method for estimating frequency response corrections for eddy covariance systems. Agric For Meterol 104:185-198

Massman WJ (2001) Reply to comment by Rannik on a simple method for estimating frequency response corrections for eddy covariance systems. Agric For Meteorol 107:247-251
Massman WJ, Lee X (2002) Eddy covariance flux corrections and uncertainties in long-term studies of carbon and energy exchanges. Agric For Meteorol 113:121-144

Miyamoto S (1983) Consumptive water use of irrigated pecans. J Am Soc Hortic Sci 108(5):676-681

Qin Z, Karnieli A, Berlinger P (2001) A mono window algorithm for retrieving land surface temperature from Landsat TM data and its application to the Israel-Egypt border region. Int $\mathrm{J}$ Remote Sens 22(18):3719-3746

Samani ZA, Hargreaves GH (1986) Data requirements for evapotranspiration estimation-discussion. J Irrig Drain Eng 111(4):410-412

Samani Z, Sammis T, Skaggs R, Alkhatiri N, Deras J (2005) Measuring on-farm irrigation efficiency with chloride tracing under deficit irrigation. ASCE J Irrig Drain Eng 131(6):555-559

Samani Z, Bawazir S, Bleiweiss M, Skaggs R, Schmugge T (2006) Estimating riparian ET through remote sensing. American Geophysical Union Fall Meeting, San Francisco

Samani Z, Bawazir S, Bleiweiss M, Skaggs R (2007a) Estimating net radiation over vegetation canopy. ASCE J Irrig Drain Eng 133(4):291-297

Samani Z, Bawazir S, Bleiweiss M, Skaggs R, Bleiweiss M, Pinon A, Tran V (2007b) Water use by agricultural crops and riparian vegetation: an application of remote sensing technology. J Contemp Water Res Educ 137:8-13

Sammis TW, Mexal JG, Miller D (2004) Evapotranspiration of floodirrigated pecans. J Agric Water Manage 69(3):179-190

Schotanus P, Nieuwstadt FTM, de Bruin HAR (1983) Temperature measurement with a sonic anemometer and its application to heat and moisture fluxes. Boundary Layer Meteorol 26(1):81-93

Skaggs R, Samani Z (2005) Farm size, irrigation practices and on-farm irrigation efficiency. Irrig Drain (ICID) 54(1):43-57

Tanner CB, Swiatek E, Greene JP (1993) Density fluctuations and use of the krypton hygrometer in surface flux measurements. In: Allen RG (ed) Management of irrigation and drainage systems: integrated perspectives. American Society of Civil Engineers, New York, pp 945-952

Van Dijk A, Kohsiek W, de Bruin HAR (2003) Oxygen sensitivity of krypton and Lyman- $\alpha$ hygrometers. J Atmos Oceanic Tech 20(1):143-151

Wang J, Sammis TW, Andales AA, Simons LJ, Gutschick V, Miller DR (2007) Crop coefficient of open-canopy pecan orchards. J Agric Water Manage 88(1-3):253-262

Webb EK, Pearman GI, Leuning R (1980) Correction of flux measurements for density effects due to heat and water vapour transfer. Quart J R Meteor Soc 106:85-100 